\title{
The Effectiveness Of Using The Meta Cognition Strategies In Teaching Mathematics On The Development Of Systemic Thinking Among The Basic Ninth Grade Students
}

\author{
Dr. Taiseer Khalil Al-qaisi, Associate Prof. \\ Tafila Technical University, Faculty of Educational Sciences, \\ Department of Curricula and Instruction, Jordan
}

doi: 10.19044/esj.2016.v12n7p346 URL:http://dx.doi.org/10.19044/esj.2016.v12n7p346

\begin{abstract}
This study aimed to investigate the effectiveness of using the meta cognition strategies in teaching mathematics on the development of systemic thinking among the basic ninth grade students in Tafila Governorate. The sample of this study consisted of two female groups; experimental and control were selected from Tafila basic school for girls, and another two male groups; experimental and control were selected from Omar bin Alkhattab basic school for Boys. The analysis unit to factors and fractures was selected; teacher's guide was prepared to be used as a teaching guide. Achievement test was set up to measure the systemic thinking among the study sample, where its reliability and validity were also confirmed. The results indicated that the level of systemic thinking did not reach the level of mastery of 75\%; where the average of the scores of the experimental group students was 25.28, which is considered less than proposed average of the level of mastery of 30, and with statistical significance, and with statistically significant differences between the mean scores of individuals in experimental and control groups in favor of the experimental group, and that there are statistically significant differences between males and females in favor of females. In light of these findings, the study recommends training the teachers on these strategies, and using the meta cognition teaching when developing the curricula. In addition, it recommends conducting similar studies on other variables such as creative thinking, critical thinking, and attitudes towards mathematics.
\end{abstract}

Keywords: Meta cognition strategies, teaching of mathematics, systematic thinking, ninth basic grade 


\section{Introduction:}

The concept of thinking about thinking (meta cognition) has emerged at the beginning of the seventies to add a new dimension to cognitive psychology, where it opens up a wide horizons for experimental studies and theoretical discussions on topics of intelligence ,thinking, memory, comprehension and learning skills (Jarwan, 2009).

This concept has been developed in the eighties, and still receives a lot of attention as a new teaching method of teaching thinking. When we think about our thinking, we become aware of what we do, so we can amend it intentionally (Abdulhameed, 2007).

Harris (2003) pointed out to a significant positive correlation between the degree of students' awareness of what they do and the meta cognition strategies they use, and the extent of their understanding of information and data, in addition to their ability to use and employ them in different learning situations.

In order to train individuals to be able to adapt to the scientific and technological changes that will occur in the future; you have to teach the students how to think through developing their ability on how to think about "Meta cognition" thinking, how the information is processed to be used in different life situations, so as to be able to innovate and exercise the thinking skills in various fields, skills, and develop their ability to self-learning and how to search for knowledge; in order to overcome the problems they face (Shihab.2010).

In light of the foregoing, students can understand mathematics well and develop their ability to think in general, and systematic thinking in particular by using metacognition strategies in the teaching of mathematics and receiving training on how to think about thinking while solving the problems related to them.

\section{Research Problem}

Mathematics is systems of relationships woven into a single curriculum and organized knowledge. Mathematics is the top model of reason and the simplest model at the same time; as these systems rely on organization and interdependence in its configuration, which implies that the disassembled information are not connected to the student's information, it will therefore have no value in his knowledge formation.

Thus, true knowledge is the one student forms and integrates into his mental structure based on his previous knowledge (Obeid \& Afaneh, 2013).

As the researcher has long experience in teaching and listening to the views of teachers of mathematics during his visits to some of the research community schools and as the researcher viewed a number of studies in this area, he found out that the students do not have the ability to deal with 
concepts in mathematics in a way showing reciprocal relationships between them and linear thinking is prevalent in most of our schools so far in the teaching and learning processes; it provides concepts or topics of any subject separate from each other, in order to lead to the interrelated knowledge based on memorization and retrieval which may help the students in passing the exams that focus on measurement of knowledge.

Based on the nature of systematic mathematics; the development of cognitive aspect, the development of cognitive processes, and mental skills relating to systemic thinking have become important requirements which helped in increasing the student's ability to form mental structures, which transfer the student from the specific to overall thinking, that means to look at things from a holistic perspective.

The researcher also noticed that mathematics teachers, in general, rely on lecturing when teaching math, which ignores and marginalizes the role of the learner; because this traditional method of teaching mathematics leads to dissatisfaction among students, and less motivation to learn mathematics. The information gained in this way will not benefit them in their lives, or solve their problems. Their relation with the information ends with the end of the study and passing exams. This mechanism in teaching will not encourage the students to think in the correct manner, therefore; it is necessary to teach students how to think through the application of instructional strategies in order to help them to use mathematical knowledge and benefit from it and give it. So, it is necessary to train the students on how to think about thinking (the use of meta cognition strategies) during the educational process of learning.

Hence, the researcher feels about the importance of implementing such a study, especially - within the limits of his knowledge - no local study in all levels of education focused on such a subject; therefore this study came with the following main question:

What is the effect of using Meta cognition strategies in the teaching of mathematics on the development of systemic thinking among the basic ninth grade students in Tafila Governorate?

\section{Objectives of the Study}

This study aims to identify the level of systematic thinking in mathematics among basic ninth grade students in the Governorate of Tafila. In addition, it identifies the impact of the use of certain meta cognition strategies in teaching mathematics on the development of systemic thinking among the basic ninth grade students compared with the traditional method. Therefore, the study seeks to answer the following question: 
Has the level of systemic thinking among the basic ninth grade students in Tafila governorate who studied mathematics using meta cognition reached the minimum level of mastery of (75\%)?

It also aims to verify the validity of the following assumptions:

1 . There were no statistically significant differences at the level of significance $(\alpha \leq 0.05)$ between the control and experimental male students groups in post systemic thinking test.

2. There were no statistically significant differences at the level of significance $(\alpha \leq 0.05)$ between the control and experimental female students groups in post systematic thinking test.

3. There were no statistically significant differences at the level of significance $(\alpha \leq 0.05)$ between the control and experimental students groups in post systemic thinking test.

\section{The importance of the Study}

The study is important for the target following persons:

1. Those in charge of teaching mathematics including (supervisors and teachers) to teach students on how to think in the problems they face, or those that face their community and try to overcome them.

2. The attention of the mathematics curriculum planners should focus on how to plan the curriculum in terms of content and activities and means of evaluating in a way that develops the capacity of learners in thinking skills in general, and in systematic thinking skills in particular.

\section{Limits of the Study}

The current study was limited to the following:

1. Basic ninth-grade students in Tafila Governorate (Tafila Basic School for Girls, and Omar bin Alkhattab Basic School for Boys).

2. Teaching "Factorization and Algebraic Fractions" unit prescribed in the mathematics text book for ninth graders for first semester of the academic year 2014/2015.

\section{Study Terms}

Meta Cognition : Concepts of meta cognition, beyond cognition, above cognition, beyond perception, thinking about thinking, consciousness thinking are synonyms of the concept of (Meta cognition), which means individual's knowledge relating to cognitive operations, mental activities, methods of learning and self-control, is used in the learning processes of remembrance, understanding, planning , managing and problem solving (Fairbrother, 2005).

Meta Cognition Strategies: Set of actions carried out by the learner to know about the mental activities, methods of learning and self-control that 
are used before, during and after learning for recalling, understanding, planning, managing, problem solving and other cognitive processes (Henson \& Eller, 2004; Shihab, 2010).

Thinking: A mental activity distinguishes man from other organisms and uses mental images, knowledge, words, numbers, signs, gestures and expressions that replace things, people and situations and different events in which the person is thinking in order to understand a particular subject or a particular position (Yunus, 2010).

Systematic Thinking: A type of thinking focuses on compound scientific implications through integrated systems that clearly showing all relationships between concepts and topics to enable the learner grasp the overall picture of the contents of the systems. Therefore, the learner focuses on the whole compound that consists of a set of components linked by ties of mutual overlapping effect and dynamic interaction (Obeid \& Afaneh, 2013).

\section{Theoretical Framework of the Study}

The development of thinking skills is essential to activate the learner's thoughts and raise his mental abilities, especially when studying mathematics, because mathematics is the language of thinking. If the learner lacks mathematical thinking, then mathematics becomes a material composed of set imitated procedures without understanding their source.

\section{Thinking Levels}

(Newman, 2000) classified thinking into two levels:

Basic level of thinking includes the patterns of thinking that require retrieval of information previously acquired, such as retrieval of information stored in memory and attention to the numbers in the previously educated laws.

Higher level of thinking includes the patterns of thinking that urge the learner to the conclusion and analysis of information. Higher level of thinking skills occur when a person gets new information, stores it in memory, then such information interrelated or arranged and evaluated to achieve the goal. Higher thinking skills mean the ability to make application, analysis, analysis, conclusion and realization of relations, proof and installation.

\section{Systematic Thinking and Levels of Thinking}

Systematic thinking is a form of higher levels of thinking. Through this mode of thinking, the individual will be able to make an overall vision of the future with regard to any subject without losing any part of that subject. That means the individual moves from specific thinking to the overall thinking which makes him/her change his/her previous view of things as far 
apart and see them as one subject with many aspects in common, i.e. he looks at things from a systematic perspective.

\section{Systemic Thinking and Mathematics} stated:

Systemic thinking includes the following skills as Menoufi, (2012)

1. Analysis of the main systems to subsystems; the ability to divide the subject into parts and realize relations between these parts.

2. The re-installation of systems components, which means the ability to assemble the different parts of the content in a unified structure combines these parts.

3. Recognize the relationships within a single system and between the system and other systems.

4. The overall vision for any subject without the subject loses its parts.

In light of the above mentioned systemic thinking skills, this kind of thinking is considered a fundamental access of mathematical thinking. Obeid (2010) confirms that the systematic thinking is used in mathematics in calculations and to proof mathematical problems and issues in general away from unproductive stereotypes.

\section{Meta cognition Skills and Systematic Thinking}

Although researchers disagreed with the historical roots of meta cognition concept, and the multiple definitions related to it. Thus, all these definitions emphasize that the concept of meta cognition is linked to:

Individual's knowledge of his personal thinking, his accuracy in the description of his thinking, self- control and how he follows-up what he is doing when preoccupied with mental activity such as solving a specific problem, monitoring quality of individual's use of such follow-up in light of his mental activity in solving this problem, and individual's beliefs in relation to the domain of his thinking, and the impact of such beliefs on his way of thinking (Obeid \& Afaneh, 2013).

Many researchers stressed that the acquisition meta cognition skills help the learner to understand and learn in a positive and effective manner, and ease the acquisition of new habits of thinking, and the acquisition of mental skills that enable independent self-learning, and control of thinking, and to improve its ability to understanding and comprehension, planning and management, problem solving (Lindstorm, 2000; Beeth, 2003; Rickey \& Stacy, 2010).

In light of the foregoing, meta cognition skills help the learner to acquire mental skills, increase the understanding and comprehension ability, and help him to acquire new habits of thinking in general. 
Due to the importance of developing the skills of meta cognition, many researchers suggested strategies for the development of systemic thinking skills including: brainstorming, concept maps, self-questioning, planning, reformulation of ideas and words of students, role-playing and simulation, daily reports and memos writing, generation of questions, diagrams, and interpretation, summary, and other (Alfatayri, 2006; Humel, 2010; Koch, 2011).

This is in addition to other strategies can be used in developing of meta cognition skills, and give the nature of the growth of basic ninth graders and their cognitive structure as well as to the nature of mathematics; then "brainstorming, generation of questions, reformulation of students' ideas and the words, and the summary have been used in teaching math unit proposed in this research.

\section{Previous Studies}

The use of meta cognition strategies, and the development of thinking skills in general and systematic thinking in particular have received the interest of some researchers in recent times at the international and regional levels.

In the field of meta cognition strategies, Alfatayri's study (2006) aimed to use meta perception strategy in the development of reading the text and philosophical tendencies skills among secondary stage students. To achieve this goal, the researcher prepared "Human and the problem of freedom from the Islamic perspective," using meta perception strategy. The researcher also prepared Reading Comprehension and achievement test regarding the concepts contained in the unit.

These tools were applied before and after teaching the unit on a sample of (72) students (36 experimental and 36 control). The results showed superiority of the experimental group students to their peers in the control group in each of the reading comprehension test and achievement test

In the same field Lee's (2002) study came in order to measure the impact of each of the meta cognition strategies with multimedia in teaching a sample of students "genes" topic and used several meta cognition strategies such as: maps of concepts, and learning through activities, similes, and the work of graphics, and examples. The researcher concluded that the use of meta cognition strategies increased students' achievement in science.

As well, the study of Bahjat (2008) aimed to measure the effectiveness of the use of meta cognition strategies in the development of food concepts and awareness of good food behavior among science teachers before the service. To achieve this goal, the researcher used concept maps strategies, maps of form (V), comprehensive approach, and brainstorming as examples of these strategies. The researcher also prepared a test for food 
concepts and a measure of awareness of food behavior, the results showed the superiority of the experimental group students to their peers in the control group in getting the food concepts and awareness of patterns of food behavior.

Shihab’s study (2010) came to identify the effect of using meta cognition strategies in learning science, developing the complementary science operations skills and innovative thinking among female students at the third preparatory grade.

To achieve this goal, the researcher reformulated "sound and light" unit in science text book prescribed for female students at the third preparatory grade in a way that helps the research sample to think about thinking, and prepared for that achievement test in the unit concepts, and a measure of the processes of complementary science and a test of innovative thinking. She applied these tools before and after teaching unit on a sample of (93) female students (including 48 students in the experimental group and 45 in the control group). The results indicated that there are statistically significant differences between the members of experimental group, and members of the control group in all tools used in the study in favor of female students in the experimental group.

In the same field Koch (2011) conducted a study to identify the impact of the use of meta cognition strategies in the development of reading comprehension of the texts of physics. He build a test of reading comprehension applied to a sample of (64) students (30 students experimental, 34 students control) before studying the unit which was prepared by using meta cognition strategies and after studying it. The results showed the superiority of the experimental group students to their peers in the control group in reading comprehension test.

Hossam El Din's study (2012) aimed to measure the effect of using meta cognition strategies in the development of reading comprehension and achievement in science for second preparatory graders. To achieve this, the researcher has chosen "Material" unit and prepared it by using meta cognition strategies for the development of reading comprehension. To evaluate the effectiveness of the unit, the researcher prepared a test of reading comprehension, and another test for achievement in science, then applied these tools on a sample of 96 students (48 students experimental, 48 students control) from the second preparatory grade in Cairo governorate, before and after teaching the unit. The results showed superiority of the experimental group students to their peers in the control group in reading comprehension test and achievement test at remembering, understanding and application levels.

In the area of systemic thinking, the researcher resorted to Menoufi's study (2012), which aimed to measure the effectiveness of Systemic 
Approach in teaching trigonometry on the thinking among secondary school students. To achieve this goal, the researcher prepared trigonometry course for the first secondary graders according to the systemic approach. He also prepared an achievement test in trigonometry and another one in systemic thinking, he applied the two tools before and after teaching the course to a sample of (104) students (52 experimental 0.52 officer), and the results indicated the presence of statistically significant differences between averages of students of the two groups in achievement test in trigonometry and systematic thinking test in favor of the experimental group.

Based on the previous discussion, I note that the current study is distinguished from previous studies for the following reasons:

- Previous studies and researches measured the effectiveness of the use of meta cognition strategies on many of the dependent variables, no study showed the impact of these strategies on the development of systematic thinking, the current study linked these two variables.

As far as the researcher knows, such type of study in various stages of education has never been conducted at the local or regional levels, hence the importance of this study.

\section{Study Procedures}

\section{Study Approach}

This study applied the experimental approach by using the system of the two groups (control and experimental), with pre and post measurement to identify the impact of the teaching model based on meta cognition strategy of the control and experimental groups.

\section{Study Population and Sample}

All basic ninth grade students in Tafila governorate for the academic year 2014/2015 Tafila Basic School for Girls and Omar Bin Khattab Basic School for Boys were selected to form a sample for the study.

\section{Study measurements}

\section{First: Study Plans}

"Algebraic Analysis Unit" prescribed for the ninth basic grades during the first semester, because the use of meta cognition strategies in teaching the concepts contained in this unit help students to be involved in thinking processes, and this helps them to transfer the impact of learning into other mathematical operations.

Teachers' Guide was prepared to be used in teaching "Algebraic Factorization" unit using some of meta cognition strategies that have been identified previously. 
Consequently, the main objective of the development of the guide is to show how math teacher uses meta cognition strategies in the functional processing of the mathematical knowledge included in the unit. So that; students could learn positively and effectively and develop their ability to think in a systemic manner.

Preparation of teachers' guide passed through the following steps:

- Identifying the general objectives of the unit.

- Identifying behavioral goals for the unit.

- Planning to teach every subject from the unit using the systemic orientation

The guide was presented in its initial formula, to a group of referees in curricula and teaching methods in order to verify the validity. The necessary adjustment was made in the light of the views of the referees.

\section{Second: The test for systemic thinking in mathematics}

The test for systemic thinking in mathematics has been constructed according to the following steps:

A) Objective of the test: the test is designed to measure systemic thinking among the basic ninth grade students (study sample) through (the analysis of the difference between the two cubic quantities, and analysis of total of two cubic quantities, and analysis of the general form of quadratic equation, find the least common denominator, greatest common factor, add and subtract algebraic fraction).

B) Formulation of the test items: The test's items were prepared in paramedical order by putting the question or concept in the top of the pyramid and listing below it what is required of the question in the form of blank cells. The students are asked to fill in the blanks; such cells are linked to the question or concept through lines or arrows. Some words are written on those lines or arrows called linking words or words of guidance to the student to facilitate the solution to the question.

C) Test validity: The test was presented, in its initial formula, to the same group of referees group to express their opinion about the validity of the test items and formulation and suitability for students in ninth grade. The referees gave a number of comments on the formulation of some of the questions because they contain more than one idea, and the need for a guide words to explain what is required from students in some of the questions. Some questions were amended in the light of the comments expressed by the referees.

D) Exploratory experimentation for testing: the test was applied, in its initial formula, on a sample of 30 female students from the ninth grade in Wadi Zeid Basic School, in order to determine: 
1. Test time: It turned out that the time required for students to answer test questions is (45 minutes).

2. Test Reliability: The test reliability was calculated using Kuder Richardson 20 (KR20) Formula 20 (KR-20), and found to be equal to (0.85) and this indicates a high degree of reliability.

\section{E) The Final Form of the Test:}

The number of test questions in its final form reached (8) including (40) sub-questions taken from all subjects of the unit. The following table shows the systemic test specifications.

Table (1) Systemic Test Specifications

\begin{tabular}{|c|c|c|c|c|}
\hline No & Subject & $\begin{array}{l}\text { No. of sub- } \\
\text { questions }\end{array}$ & Relative weight & $\begin{array}{l}\text { The degree } \\
\text { given to it }\end{array}$ \\
\hline 1 & $\begin{array}{l}\text { Tri-boundary } \\
\text { analysis }\end{array}$ & 5 & $12.5 \%$ & 5 \\
\hline 2 & $\begin{array}{l}\text { Analyzing the difference } \\
\text { between two squares }\end{array}$ & 5 & $12.5 \%$ & 5 \\
\hline 3 & $\begin{array}{l}\text { Analyzing the sum of two } \\
\text { cubes }\end{array}$ & 4 & $10.0 \%$ & 4 \\
\hline 4 & $\begin{array}{l}\text { Analyzing the difference } \\
\text { between two cubes }\end{array}$ & 5 & $12.5 \%$ & 5 \\
\hline 5 & $\begin{array}{c}\text { Least Common } \\
\text { Denominator }\end{array}$ & 6 & $15.0 \%$ & 6 \\
\hline 6 & Greatest Common Factor & 4 & $10.0 \%$ & 4 \\
\hline 7 & $\begin{array}{l}\text { Fractions } \\
\end{array}$ & 5 & $12.5 \%$ & 5 \\
\hline 8 & $\begin{array}{l}\text { Addition \& subtraction of } \\
\text { Algebraic fractions }\end{array}$ & 6 & $15.0 \%$ & 6 \\
\hline & Total & 40 & $100 \%$ & 40 \\
\hline
\end{tabular}

\section{Fourth: the Experimental Design of the Study:}

1. Selection of the study sample: two basic ninth grades in Tafila Basic School for Girls and two basic ninth grades in Omar Bin Khattab School for Boys were selected. Each of two classes represent experimental and control group in the same school. The following table shows the sample of the study.

Table (2) The study sample specifications.

\begin{tabular}{|c|c|c|c|}
\hline Group & Gender & Number & Total \\
\hline Experimental & Males & 31 & 63 \\
& Females & 32 & \\
\hline Control & Males & 30 & 62 \\
& Females & 32 & $\mathbf{1 2 5}$ \\
\hline \multicolumn{2}{|r|}{ Total of the two groups }
\end{tabular}

- Equality of the two groups (control and experimental): Equality of the two groups was confirmed in the following variables:

A) achievement in mathematics: The differences between the averages of the two groups (control and experimental) in mathematics 
achievement for the first semester were calculated and the results are as shown in the following table:

Table (3) Averages, standard deviations, and (T) values of the results of student achievement in the first semester in math for the two groups (control and experimental).

\begin{tabular}{|c|c|c|c|c|c|c|c|}
\hline Gender & Group & Number & $\begin{array}{l}\text { Total } \\
\text { Score }\end{array}$ & Average & $\begin{array}{c}\text { Standard } \\
\text { Deviation }\end{array}$ & $\begin{array}{c}(\mathrm{T}) \\
\text { value }\end{array}$ & $\begin{array}{c}\text { Statistical } \\
\text { Significance }\end{array}$ \\
\hline \multirow[t]{2}{*}{ Males } & Control & 30 & 50 & 22.36 & 8.12 & \multirow[t]{2}{*}{0.25} & \multirow{2}{*}{$\begin{array}{c}\text { Not } \\
\text { significant }\end{array}$} \\
\hline & Experimental & 31 & 50 & 23.12 & 7.88 & & \\
\hline \multirow[t]{2}{*}{ Females } & Control & 32 & 50 & 21.23 & 8.52 & \multirow[t]{2}{*}{0.96} & \multirow{2}{*}{$\begin{array}{c}\text { Not } \\
\text { significant }\end{array}$} \\
\hline & Experimental & 32 & 50 & 22.31 & 8.36 & & \\
\hline \multirow{2}{*}{$\begin{array}{l}\text { Males\& } \\
\text { Females }\end{array}$} & Control & 62 & 50 & 23.15 & 8.56 & \multirow[t]{2}{*}{1.01} & \multirow{2}{*}{$\begin{array}{c}\text { Not } \\
\text { significant }\end{array}$} \\
\hline & Experimental & 63 & 50 & 22.41 & 8.41 & & \\
\hline
\end{tabular}

Table (3) shows no statistically significant differences between the control and experimental groups (male control and male experimental as well as female control and female experimental, in addition to male and female members of the control group and male and female members of the experimental group) in the achievement in mathematics, which means that the two groups experimental and control are equivalent in this variable.

\section{B) Pre- systemic thinking test:}

The systematic thinking test was applied on the two groups of the research before starting the study, to learn about the extent of equality of the two groups in this variable, and the results of the pre- test application are shown in table (4):

Table (4) Averages, standard deviations, and (T) values of the results of pre-application of study tool to the two groups (control and experimental).

\begin{tabular}{|c|c|c|c|c|c|c|c|}
\hline Gender & Group & Number & $\begin{array}{l}\text { Total } \\
\text { Score }\end{array}$ & Average & $\begin{array}{c}\text { Standard } \\
\text { Deviation }\end{array}$ & $\begin{array}{l}(\mathrm{T}) \\
\text { value }\end{array}$ & $\begin{array}{c}\text { Statistical } \\
\text { Significance }\end{array}$ \\
\hline \multirow[t]{2}{*}{ Males } & Control & 30 & 40 & 12.21 & 4.52 & \multirow[t]{2}{*}{1.2} & \multirow{2}{*}{$\begin{array}{c}\text { Not } \\
\text { significant }\end{array}$} \\
\hline & Experimental & 31 & 40 & 12.44 & 5.61 & & \\
\hline \multirow[t]{2}{*}{ Females } & Control & 32 & 40 & 13.45 & 5.36 & \multirow[t]{2}{*}{1.56} & \multirow{2}{*}{$\begin{array}{c}\text { Not } \\
\text { significant }\end{array}$} \\
\hline & Experimental & 32 & 40 & 13.25 & 4.27 & & \\
\hline \multirow{2}{*}{$\begin{array}{l}\text { Males\& } \\
\text { Females }\end{array}$} & Control & 62 & 40 & 12.68 & 6.36 & \multirow[t]{2}{*}{1.06} & \multirow{2}{*}{$\begin{array}{c}\text { Not } \\
\text { significant }\end{array}$} \\
\hline & Experimental & 63 & 40 & 12.36 & 4.39 & & \\
\hline
\end{tabular}

Table (4) shows no statistically significant differences between the control and experimental groups (male control and experimental as well as female control and experimental, in addition to control group as a whole and experimental group as a whole) in the pre-systematic thinking test, which means that the two groups experimental and control are equivalent in this variable.

\section{Teaching process}

After the researcher has finished the pre-application of the systematic thinking test, the math teacher in Omar Bin Khattab Basic School for Boys, 
and math teacher in Tafila Basic School for Girls were asked to teach the math unit in their schools. Several meetings were held with the two teachers to provide them on how to employ meta cognition strategies in the teaching of mathematics. After the researcher has become ascertained that the two teachers master these strategies in teaching mathematics, he asked them to write down their observations about students during the implementation of the experiment. The researcher attended some classes to check on the progress of the teaching process in the research groups at both schools. He noted students' good response and their keenness to learn by using these strategies. The students also showed a clear positive interaction and participation during the teaching of the unit. The teaching of the experimental unit took one month, about five classes per week with (45) minutes for each class.

\section{Post -application of study measurement}

Upon the end of teaching the unit to the research two groups, with the help of the two teachers, the researcher applied the post systemic thinking test on the two groups.

\section{Results of the study and discussion}

For answering the study question: Did the level of systemic thinking among basic ninth grade in Tafila governorate who studied mathematics using meta cognition strategies reach (75\%) which is the minimum level of mastery? To answer this question.

The averages of members of the experimental group at the post systemic thinking test was calculated and found to be (25.28) with a standard deviation of (6.36). Additionally, the estimated average corresponding to (75\%) was calculated as follows:

\section{The estimated average $=($ total test score $) \times(75 \%)=\mathbf{4 0} \times \mathbf{7 5 \%}=\mathbf{3 0}$}

To calculate the significance of differences between the real and estimated averages, $(\mathrm{T})$ test was used for one sample as follows: (Afaneh, 1998, p. 39).

\section{$\mathbf{T}=$ (estimated average - real average $) \div$ standard error}

After conducting statistical calculations, it turns out that the value of $(T)=5.32$, statistically significant at less than (0.01) level, and therefore the results indicate the presence of statistically significant differences in the level of systemic thinking between the estimated and real averages and in favor of the estimated average, which means that the members of the experimental sample did not reach the required mastery level about (75\%). 


\section{This result attributable to}

- The period given for the experimental group to train on systematic thinking was not enough to raise the level of their systematic thinking to the level of mastery of $75 \%$.

- The students were not previously trained on how to use meta cognition strategizes that have been proposed for the experimental sample, despite the fact that meta cognition strategies that have been used with the experimental sample had significantly raised the level of their systematic thinking, and this is also indicated by their averages in pre and post systemic thinking test, in addition to the results of hypothesis validity test

\section{Test of the first hypothesis}

First null hypothesis of the study states that "there are no statistically significant differences at the level of significance $(\alpha \leq 0.05)$ between the control and experimental groups of male students in post systemic thinking test.

To test this hypothesis, averages, standard deviations, and (T) values for scores of male students in the control and experimental groups in post systemic thinking test were calculated, as table (5) shows..

Table (5) Averages, standard deviations, and (T) value of the results of the post application of systematic thinking test to male students in the control and experimental groups.

\begin{tabular}{|c|c|c|c|c|c|}
\hline Group & Number & Average & $\begin{array}{c}\text { Standard } \\
\text { Deviation }\end{array}$ & $\begin{array}{c}\text { (T) } \\
\text { Value }\end{array}$ & $\begin{array}{c}\text { Significance } \\
\text { Level }\end{array}$ \\
\hline Experimental(Males) & 31 & 26.13 & 7.98 & 6.24 & $\begin{array}{c}\text { Significant at } \\
0.01\end{array}$ \\
\hline Control (Males) & 30 & 15.85 & 6.12 & & \\
\hline
\end{tabular}

Table (5) shows that there are statistically significant differences between the averages of the experimental group of male students, and the averages of their peers in the control group in post application of the systematic thinking test, and in favor of the experimental group. Thus, the first null hypothesis is rejected. This means that the teaching of "Algebraic Factorization" unit by using meta cognition strategies contributes to the development of systematic thinking among males students better than the traditional method used in the teaching of mathematics. To find out the effectiveness of the use of meta cognition strategies in the teaching of the proposed mathematics unit in the development of systematic thinking among ninth graders (male), the researcher calculated the effect of the independent variable on the dependent variable size as follows:

\section{The effect size}

The researcher used Eta Squared " $\eta 2$ " to determine the effect of the independent variable size: the strategies beyond the knowledge on the dependent variable: the systemic thinking. 
" ๆ2"" can be calculated after calculating (T) value using the following equation:

$$
\eta 2=\frac{t^{2}}{t^{2}+d f} \text { (Kiess, 1994) }
$$

Where "t2" is the square value $(\mathrm{T})$, $\mathrm{df}$ are degrees of freedom, then calculate the value of (d), which reflects the effect size by using the following equation:

$$
\mathrm{d}=\frac{2 \sqrt{\eta^{2}}}{\sqrt{1-\eta^{2}}} \text { (Kiess, 1994) }
$$

Using statistical methods to calculate the values of $\eta 2$, (d). The results came as described in the following table:

Table (6) ( $\eta 2$ ) value and the corresponding (d) value and the effect size.

\begin{tabular}{|c|c|c|c|c|}
\hline $\begin{array}{c}\text { Independent } \\
\text { Variable }\end{array}$ & $\begin{array}{c}\text { Dependent } \\
\text { Variable }\end{array}$ & $(\eta 2)$ Value & (d) Value & Effect size. \\
\hline $\begin{array}{c}\text { Meta cognition } \\
\text { strategies }\end{array}$ & $\begin{array}{c}\text { Systematic } \\
\text { thinking (males) }\end{array}$ & 0.61 & 1.26 & *Large \\
\hline
\end{tabular}

* Value $(\mathrm{d})=0.2$ (small effect size), and value $(\mathrm{d})=0.5$ (medium effect size), and value (d) $=0.8$ (large effect size)

Table (6) shows that the effect of the independent variable size (meta cognition strategies) on the dependent variable (systemic thinking among male students) is large, because the (d) value is greater than (0.8). This can be explained on the basis that the value of $(\eta 2)=61 \%$ of the total variation of the variable (systematic thinking) refers to the independent variable (meta cognition strategies).

Tables (5) and (6) show that the (T) value is statistically significant and the effect of the independent variable size (meta cognition strategies) is large on the dependent variable (systematic thinking among males), and this shows the effectiveness of the use of meta cognition strategies on the development of systemic thinking among male students in the ninth grade, and the superiority of these strategies compared to the traditional or usual method in the teaching of mathematics on the development of this kind of thinking.

\section{Test the second null hypothesis}

The second null hypothesis of the study states that "there are no statistically significant differences at the level of significance $(\alpha \leq 0.05)$ between the control and experimental of female students groups in post systemic thinking test. 
To test this hypothesis, averages, standard deviations, and (T) values for scores of female students in the control and experimental groups in post systemic thinking test were calculated, and the following table shows these results.

Table (7) Averages, standard deviations, and (T) value of the results of the post application of systematic thinking test to female students in the control and experimental groups.

\begin{tabular}{|c|c|c|c|c|c|}
\hline Group & Number & Average & $\begin{array}{c}\text { Standard } \\
\text { Deviation }\end{array}$ & $\begin{array}{c}\text { (T) } \\
\text { Value }\end{array}$ & $\begin{array}{c}\text { Significance } \\
\text { Level }\end{array}$ \\
\hline $\begin{array}{c}\text { Experimental } \\
\text { (Females ) }\end{array}$ & 32 & 27.23 & 8.65 & 9.36 & $\begin{array}{c}\text { Significant at } \\
0.01\end{array}$ \\
\hline $\begin{array}{c}\text { Control (Females } \\
\text { ) }\end{array}$ & 32 & 16.35 & 6.12 & & \\
\hline
\end{tabular}

Table (7) shows that there are statistically significant differences between the averages of the experimental group students (females) and the averages of their peers in the control group in post application of the systematic thinking test, and in favor of the experimental group. Thus, the second null hypothesis is rejected.

This means that the teaching of "Algebraic Factorization" unit by using meta cognition strategies contributes to the development of systematic thinking among female students better than the traditional method used in the teaching of mathematics. To find out the effectiveness of the use of meta cognition strategies in the teaching of the proposed mathematics unit in the development of systematic thinking among ninth graders (females), the researcher calculated the effect of the independent variable on the dependent variable size as follows:

Table (8) ( $\eta 2)$ value and the corresponding (d) value and the effect size.

\begin{tabular}{|c|c|c|c|c|}
\hline $\begin{array}{l}\text { Independent } \\
\text { Variable }\end{array}$ & Dependent Variable & 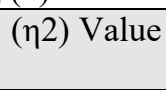 & (d) Value & $\begin{array}{l}\text { Effect } \\
\text { size. }\end{array}$ \\
\hline $\begin{array}{l}\text { Meta cognition } \\
\text { strategies }\end{array}$ & $\begin{array}{l}\text { Systematic thinking } \\
\text { (females) }\end{array}$ & 0.68 & 2.74 & Large \\
\hline
\end{tabular}

Table (8) shows that the effect of the independent variable size (meta cognition strategies) on the dependent variable (systemic thinking among female students) is large, because the (d) value is much greater than (0.8). This can be explained on the basis that the value of $(\eta 2)=68 \%$ of the total variation of the variable (systematic thinking) refers to the independent variable (meta cognition strategies).

Tables (7) and (8) show that the (T) value is statistically significant and the effect of the independent variable size (meta cognition strategies) is large on the dependent variable (systematic thinking among males), and this shows the effectiveness of the use of meta cognition strategies on the development of systemic thinking among female students in the ninth grade, and the superiority of these strategies compared to the traditional or usual 
method in the teaching of mathematics on the development of this kind of thinking.

\section{Test the validity of the third null hypothesis}

The third null hypothesis of the study states that "there are no statistically significant differences at the level of significance $(0.05 \geq \alpha)$ between the control and experimental students groups (males females) in the post systemic thinking test.

To test the validity of this hypothesis, averages, standard deviations, and (T) values for scores of (male and female) students in the control and experimental groups in the post application of systemic thinking test were calculated, and the following table shows these results.

Table (9) Averages, standard deviations, and (T) value of the results of the post application of systematic thinking test to the control and experimental groups.

\begin{tabular}{|c|c|c|c|c|c|}
\hline Group & Number & Average & $\begin{array}{c}\text { Standard } \\
\text { Deviation }\end{array}$ & $\begin{array}{c}\text { (T) } \\
\text { Value }\end{array}$ & $\begin{array}{c}\text { Significance } \\
\text { Level }\end{array}$ \\
\hline $\begin{array}{c}\text { Experimental } \\
\text { (males females })\end{array}$ & 63 & 26.74 & 8.21 & 10.23 & $\begin{array}{c}\text { Significant at } \\
0.01\end{array}$ \\
\cline { 1 - 3 } (males \& females) & 62 & 15.84 & 6.32 & & \\
\hline
\end{tabular}

Table (9) shows that there are statistically significant differences between the averages of the experimental group students (males and females) and the averages of their peers in the control group in post application of the systematic thinking test, and in favor of the experimental group. Thus, the null hypothesis is rejected.

This means that the teaching of "Algebraic Factorization" unit to the ninth graders by using meta cognition strategies contributes to the development of systematic thinking among students is better than the traditional method used in the teaching of mathematics.

To find out the effectiveness of the use of meta cognition strategies (independent variable) on the development of systematic thinking (dependent variable), the effect size was calculated as follows:

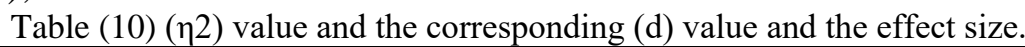

\begin{tabular}{|c|c|c|c|c|}
\hline $\begin{array}{c}\text { Independent } \\
\text { Variable }\end{array}$ & Dependent Variable & ( $) 2$ Value & (d) Value & $\begin{array}{c}\text { Effect } \\
\text { size. }\end{array}$ \\
\hline $\begin{array}{c}\text { Meta cognition } \\
\text { strategies }\end{array}$ & $\begin{array}{c}\text { Systematic thinking } \\
\text { (males \&females) }\end{array}$ & 0.64 & 2.36 & Large \\
\hline
\end{tabular}

Table (10) shows that $(\mathrm{d})$ value $=2.36$, is greater than (0.8) which proves that meta cognition strategies have considerable effect on the development of systematic thinking among ninth grade students, as well as the superiority of these strategies in teaching mathematics to the 
experimental group students compared to the traditional method used in teaching mathematics to the control group students.

This result can be explained on the basis that the value of $(\eta 2)=64 \%$ of the total variation of the variable (systematic thinking) refers to the independent variable (meta cognition strategies).

\section{Interpretation of the results of the first, second, and third hypothesis:}

Testing the validity of first, second, and third hypothesis showed that there is a significant effect for the use of meta cognition strategies in teaching the math unit proposed in this study on the development of the systemic thinking among ninth graders, and these results are attributable to the following:

The use of some meta cognition strategies such as brainstorming, questions generation, ideas reformulation and summarize the information during the teaching of the math unit proposed in this study, have provided many opportunities for these students, as follows:

1. When learning the content of the unit, the students began using mental processes associated well with that content. Therefore, their learning will be effective, and they will play a positive and active role in the educational process.

2. Use meta cognition strategies to think about thinking, and the practice of multiple mental activities, which in turn helps to understand the knowledge and information contained in the proposed study unit in a holistic manner and in a form of pieces clearly reflecting all relations between such knowledge and information. This new image is considered new for the student because he used to see thing as parts separated from each other, and this in turn has helped the development of systemic thinking.

3. Design their own systems during the class, and this significantly improves the level of their systemic thinking.

Regarding the agreement or disagreement of this study results with the results of previous researches and studies, it has been previously explained that, as far as the researcher know, neither study have been conducted about the link between meta cognition strategies and the development of systematic thinking . However, in general the use of meta cognition strategies positively affect students' achievement, and this is indicated by the results of (Lee, 2002), and (Hossam El Din, 2012) studies, or in the development of some kinds of thinking, such as (Shihab, 2010) study, where the results of the study indicated the presence of significant effect for the use of meta cognition strategies in the development of innovative thinking. 


\section{Recommendations and proposals}

In the light of the outcomes, limits and approach of the study, the recommendations and proposals could be made as follows:

\section{First: Recommendations}

1. The result of the study question indicated that the level of systemic thinking of students in the study sample was not up to the level of mastery (75\%). In the light of this result the researcher recommends students' continuous training on the use of systematic thinking through the meta cognition strategies used by teachers to upgrade students in this kind of thinking.

2. The results of the first, second and third hypotheses indicated the significant effect of using meta cognition strategies on the development of systematic thinking among members of the study sample. In the light of these results the following recommendations are made:

A) Holding training courses or workshops for in-service teachers, particularly mathematics teachers, especially in public schools to be trained on how to use meta cognition strategies in the educational / learning process

B) Training pre-service teachers at colleges of education in Jordanian universities on how to use and employ meta cognition strategies in the planning and implementation of the math classes, and through the course of methods of teaching mathematics, micro-teaching or field training

C) Urging math teachers to focus on the use of meta cognition strategies, given the significant effect of those strategies on improving students' level in systematic thinking.

\section{Second proposals}

To complete the effort in this study, the researcher recommends the following that such studies should be conducted relating the following:

1. Study the effect of meta cognition strategies on other variables such as creative thinking, critical thinking, attitudes towards mathematics.

2. Study mathematics teachers' attitudes towards the use of meta cognition strategies in teaching and learning.

3. Develop a proposed program to train mathematics teachers on using meta cognition strategies in the teaching and learning of mathematics and ensure its effectiveness.

4. Study the level of systemic thinking among students of various school stages.

5. Study the effect of the use of meta cognition strategies in the teaching of engineering on the development of systematic thinking. 


\section{References:}

Alfatayri, S. (2006). Effectiveness of the use of meta perception strategy on the development of the skill of reading the text and philosophical tendencies in the secondary stage. Journal of the College of Education in Zagazig, (27), 225-255.

Bahjat, R. (2008). Effectiveness of use of meta cognition strategies over in the teaching of food education and awareness of food behavior among science teachers - before the service. Unpublished Dissertation, Jordan University, Amman.

Beth, M.E. (1998): Teaching the conceptual change: using status as Meta cognitive Tool, science Education,82(3).

Defors, M., \& Al-Najjar, M. (2007). The role of mathematics curriculum in the development of higher-order thinking skills. The Future of the Arab Education Journal, 3(9,10), 169-194.

Jarwan, F. (2009). Teaching thinking, concepts and applications. Jordan: University Book House.

Henson, K . T. \& Eller, B.F. (1999): Educational psychology for Effective Teaching, second Edition, Boston, London, New York, Wadsworth publishing company .

Hossam El Din, L.(2012). Effectiveness of the use of meta cognition strategies on the development of comprehension and achievement in science among second prep students. Journal of Education, 5 (4), 1-125.

Hummel, S. (2000): Developing comprehension skills of , ( secondary student with specific learning Difficulties), Australian Journal of learning Disabilities, 5 (4) , p.p.33-37.

Kiess. H. (1989): statically concepts for the Behavioral Science, Canada Sydney Toronto Allyn \& Bacon.

Koch, A (2001): Training in Meta cognition: (Meta cognition and comprehension of physics, Texts Science Education.85, (6) P.P.758 - 768.

Lee P.L. (1997): Integrating concept Mapping and Meta cognitive methods in Hypermedia Environment for learning Science , D. A. I. 59.(11A). P. 4046.

Lindstorm, C. (1995): Empower the child with learning Difficulties to think Meta cognitively, Australian Journal of Remedial Education, 27(2), 23 -29.

Mayers, L. (1988): analyze is of students out comes in ninth Grade physical science thought with a science, technology, society Focus versus and Thought with a Textbook orientation, , D. A. I . 50 (14), p1254.

Manoufi, S. (2012). Effectiveness of the use of the systematic approach in teaching trigonometry and its effect on the systematic thinking among secondary school students. The Egyptian society of curricula and teaching methods, $14^{\text {th }}$ Congress, the education curriculum in the light of the concept of performance. 
National Center for Educational Research and Development (2006). Teaching to develop the supreme skills of thinking. Series of translated books (2).

Obeid, W. (2010). Meta cognition, the concept and significance, the Egyptian society for reading and knowledge. Reading and knowledge Journal, 8(5), 12-24.

Obeid, W. \& Afaneh, I. (2013). Thinking and school curriculum. Kuwait, AlFalah publishing \& distribution house.

Rickey, D \& stacy, A., (2000): the Role of Meta cognition in learning chemistry, Journal of chemical Education, 77 (7), 12-18.

Shihab, M.(2010). Effectiveness of the use of meta cognition strategies on science achievement and the development of complementary science operations skills and innovative thinking among third preparatory grade students. Journal of Education, 3 (4), 1-40.

Schraw, G. \& Dennison, R (1994): An assisting Meta cognitive Awareness, contemporary, Educational psychology. 19 (4), 65-71.

Yore, L. et al. (1998): under of science reading a awareness: An Interactive constructive model, Test verification and Grades $4-8$ result, Journal of research in science teaching 35(1), 54-64.

Yunus, F. (2010). Readings in thinking skills and teaching critical and creative thinking. Arab Renaissance House, Cairo. 